\title{
‘Pitstop of Death': Irish newspaper coverage of Iraq war protests at Shannon airport
}

\author{
Harry Browne, Colin Coulter, Roddy Flynn, Vanessa Hetherington \& Gavan \\ Titley
}

To cite this article: Harry Browne, Colin Coulter, Roddy Flynn, Vanessa Hetherington \& Gavan Titley (2019) 'Pitstop of Death': Irish newspaper coverage of Iraq war protests at Shannon airport, Irish Political Studies, 34:1, 92-112, DOI: 10.1080/07907184.2018.1515073

To link to this article: https://doi.org/10.1080/07907184.2018.1515073

\section{Published online: 03 Sep 2018.}

Submit your article to this journal $\square$

山 Article views: 70

View Crossmark data $\longleftarrow$ 


\title{
'Pitstop of Death': Irish newspaper coverage of Iraq war protests at Shannon airport*
}

\author{
Harry Browne ${ }^{a}$, Colin Coulter ${ }^{b}$, Roddy Flynn ${ }^{c}$, Vanessa Hetherington ${ }^{d}$ and \\ Gavan Titley
}

${ }^{a}$ School of Media, Dublin Institute of Technology, Dublin, Ireland; ${ }^{b}$ Department of Sociology, Maynooth University, Maynooth, Ireland; 'School of Communications, Dublin City University, Dublin, Ireland; ${ }^{d}$ Independent Scholar, Dublin, Ireland; ${ }^{e}$ Department of Media Studies, Maynooth University, Maynooth, Ireland

\begin{abstract}
The airport at Shannon, County Clare, in the west of Ireland, has been a strategically important US military stopping-point in the wars of the twentyfirst century and consequently has at times become a focal point for the various forms of protest that have been adopted by the Irish peace movement. This study, drawing upon a database of Irish national newspaper articles dealing with the anti-war movement from September 2002 to May 2003 - a period covering the build-up to the invasion of Iraq to its immediate aftermath - examines how the US military's use of Shannon and the protests against it were framed in the print media. The focus on Shannon made Irish media coverage different from that in other European countries: the authors find that a period of Irish government equivocation about the military significance of the airport permitted campaigners to attract some sympathetic attention by providing information about troop movements there successfully promulgating a 'counterframe', i.e. a news frame that ran counter to the government line - but that as the war approached this gave way to a newspaper focus on the dangers of protest, including the ascription of violence.
\end{abstract}

KEYWORDS Ireland; anti-war movement; Iraq War; media coverage of protest

\section{Introduction}

The landing strip outside Shannon represents a first landfall for flights crossing the Atlantic, giving the facility a geopolitical significance that belies its status as a small regional airport. Over the course of several decades, troops from the United States and elsewhere have passed through the County Clare location on their way to bases and theatres of conflict farther afield. In the 15 months that preceded the invasion of Iraq, there were more than 100,000 journeys

CONTACT Colin Coulter colin.coulter@mu.ie

${ }^{*}$ Newspapers cited (dates specified in text): Evening Herald, Ireland on Sunday, Irish Daily Star. Irish Examiner, Irish Independent, Irish Times, Sunday Business Post, Sunday Independent, Sunday Tribune, Sunday World.

(C) 2018 Political Studies Association of Ireland 
through the facility by US troops, with almost 35,000 of these in the 11 weeks alone that preceded the onset of hostilities (Allen \& Coulter, 2003; Doris, 2007). In late 2002 and January 2003, reports and images of US soldiers passing time in Shannon Airport led to public discussion about how this reflected, and affected, Ireland's traditional status as a 'neutral' state.

While the notion of neutrality has a resonance within Irish political culture, it remains a nebulous concept (Tonra, 2006, pp. 153-80). The idea of a 'neutral' Ireland is held dear, or at least paid lip service, by a spectrum of opinion that ranges from an autarkic nationalism at one pole to an advocacy of participation in the nascent military structures of an enlarged Europe at the other. In between these outliers is by far the most prevalent position on 'neutrality', one that insists that Ireland should only participate in military operations that are sanctioned by the 'surrogate' (Tonra, 2006, p. 180) of a United Nations mandate. The American troops stopping at Shannon were on their way to take part in a prospective war that lacked such approval. The Irish government, when forced to comment, stated that allowing US-military use of the airport did not constitute participation in any war (Miller, 2005, p. 173). US diplomatic cables later released by Wikileaks show that events at the airport and the public debate about its use were a high priority for both the US and Irish governments (Browne, 2011). The focus by some protesters on Shannon, and the tactics that they employed to highlight what was happening at the airport, became a source of dissension within the anti-war movement in 2003 (see below, and Browne, 2008).

The present paper, focussing on press treatment of Shannon Airport as a site of protest, is part of a wider study, the purpose of which is not to examine coverage of the war itself, or even of the debate preceding and around it, but rather to focus directly on coverage of the protest movement. One of the ambitions of our research is to explore the circumstances in which mainstream coverage of protest activity may be at least neutral and perhaps even sympathetic. In doing so, we contribute to a body of recent literature that attempts to locate media treatment of social movements within a 'protest paradigm', which is to say the identification of a pattern or set of patterns that govern how journalism treats such movements (McLeod \& Detenber, 1999; Power, Haynes, \& Devereux, 2016), as well as to research that maps the limits of such a paradigm (Shahin, Zheng, Sturm, \& Fadnis, 2016). In one version of the paradigm, Gottlieb (2015) suggests there is a cycle in which growing protest campaigns may garner positive attention for their grievances before the coverage moves to a focus on conflict and negativity. Lee (2014) and Boyle, McLeod, and Armstrong (2012) suggest protest tactics may be more relevant than goals in triggering negative coverage of specific campaigns. The idea of a paradigmatic cycle and the hypothesis that coverage responds principally to tactics are not necessarily mutually exclusive, and this paper aims to shed more light upon the circumstances in which press coverage might, on the one hand, focus positively on information coming from protesters and, on the other, cast a negative light on protest tactics. 
As O'Regan (2010) points out, in late 2002 and early 2003, some major European governments appeared to support a version of the wider argument opposing the invasion of Iraq, strengthening the salience, from the perspective of the media, of the anti-war position in Ireland, as elsewhere. In this context, we examine whether campaigners at Shannon Airport were able to promulgate a 'counterframe' (Entman, 2004, pp. 17-20), a way for journalists to frame stories that resists the hegemonic narrative of Irish co-operation with American efforts - protesters being treated as sources whose own framing was consonant with journalists' news frames (see Baden \& Tenenboim-Weinblatt, 2018).

Previous research into the prelude to the Iraq War in the winter of 2002-3 has pointed to an overwhelming pro-war media consensus in the United States (Tumber \& Palmer, 2004; Hayes \& Guardino, 2010), but something quite different in Europe (Dimitrova \& Strömbäck, 2008; Robinson, Goddard, Parry, Murray, \& Taylor, 2010), where the impending war was regarded as existing in the sphere of 'legitimate controversy' (Hallin, 1986) and covered accordingly. Elsewhere in Europe, such legitimacy lasted until the bombing started; our study examines whether the peculiarities of the Irish situation, notably the role of Shannon Airport and the tactical arguments about protest there, meant that Irish media coverage of anti-war protests in fact became more negative in the weeks before the war began on 19 March 2003.

While the timeframe of our research is relatively extensive it remains limited nonetheless, meaning that even if we discern that there was a successful counterframe promulgated by campaigners, we cannot test Cottle's relatively optimistic and broader conclusion (2008, p. 867) about increased media openness to protest movements 'in a more complex media ecology and network of communication flows', an optimism about the direction of change in twenty-first century coverage of protest that is shared by Lee (2014). Our findings do suggest, however, that there exists at times a specific information environment in which such optimism could be justified, corresponding in part to what Cammaerts $(2012$, p. 130) calls a 'mediation opportunity structure', a space for campaigners to gain traction with 'counterspin'.

Along with the assessment of counterframing, the questions of whether and, if so, how the press associated violence with protest are central to our research. Gitlin (1980) famously included 'emphasis on violence at demonstrations' as one of the nine standard frames by which the mass media organise discourse about public expressions of political dissent. He quotes Norman Mailer: 'The media are waiting there, like coiled springs, hoping that a few maniacs will cut loose' (Gitlin, 1980, p. 7). As Halloran, Elliott, and Murdock (1970) wrote of the coverage of an anti-war demonstration in London: 'Viewers and readers were not presented with various interpretations focusing on different aspects of the same event, but with basically the same interpretation which focused on the same limited aspect - the issue of violence.' (300). We examine the extent to which such framing occurred in relation to Shannon 
Airport protests, and how protesters' direct-action tactics, in particular, were associated by journalists with a depoliticised framing - that is, one treating protests predominantly in terms of crime and law enforcement rather than as political actions (see Maeseele, Raeijmaekers, Van der Steen, Reul, \& Paulussen, 2017). There is a particularly acute and indeed painful irony when 'violence' comes to dominate coverage of a movement to prevent a war that would result in the deaths of hundreds of thousands of people.

The worldwide campaign of opposition to the prospect of a US-led invasion of Iraq represents arguably the most important transnational social movement ever to have existed. On 15 February 2003, for instance, 'over 10 million people' (Seppälä, 2012, p. 1) marched in 'at least 800 cities' (Nineham, 2013, p. 29) in what was 'the most global protest in history' (Gillan, Pickerill, \& Webster, 2008, p. 113). The unprecedented size and truly worldwide nature of the movement against the Iraq War lends it a special and enduring significance (Barbrook, 2007, p. 288; Seppälä, 2012). This has not been acknowledged sufficiently, however, in the academic studies of media coverage of the period. There have been a host of valuable studies of how journalists reported the Iraq War published over the last decade and a half (Carruthers, 2011; Miller, 2004; Mirzoeff, 2005; Tumber \& Palmer, 2004). In the main, however, these have failed to provide focused or sustained accounts of how the anti-war movement was mediated. There are some exceptions to this trend, however, such as the work of Robinson et al. (2010), who provide a substantial and finely detailed analysis of how dissenting voices against the conflict were depicted in the British print and broadcast media (see also: Taylor [2015; 2017]). The research that we conducted is in part an attempt to supplement such work and further redress the imbalance in academic accounts of the media coverage of one of the defining geopolitical events of this century. Drawing on one of the largest databases of its type ever assembled in Ireland, this paper examines the complex and variable ways in which the press represented the anti-war movement in a national context in which opposition to the invasion of Iraq was especially strong, not least because it had its own very specific rationale in relation to Shannon Airport. And while the focus of our research falls not on the movement per se bur rather its representation, it is hoped that such a comparatively rare, in an Irish context at least, longitudinal study of press and protest will also shed light on the public politics of resistance, at what was an intriguing moment in the history of Ireland's relations with the wider world.

\section{The research database}

This paper draws upon our comprehensive database of a nine-month period of news coverage of anti-war activities in the Irish national press, examining all content relating to the anti-war movement, in whole or in part, in the 'home 
news' and 'world news' pages of eleven newspapers, comprising the major national titles that generated most of the news content in Ireland. At the outset, it had been our intention to gather data not only on the press but also on the broadcast media. It soon became apparent, however, that the costs of accessing the relevant archives would be prohibitive. Gaining access to television reports alone would have consumed our research budget many times over. As a consequence, we decided at an early stage to restrict ourselves to newspapers. This more narrow focus would, however, generate a wealth of material, which is, hopefully, apparent in the detail documented in this paper. The newspaper titles examined were the Evening Herald, Irish Daily Star, Irish Examiner, Irish Independent, Irish Times, Sunday Business Post, Sunday Independent, Sunday World, Sunday Times, Sunday Tribune, and Ireland on Sunday - the last two titles now defunct between 1 September 2002 and 31 May 2003. (The Sunday Times in question is the Irish edition of the Murdoch-owned British paper. All of the news content in that paper included in our analysis was Irish generated.) The eleven newspapers selected cover a diversity of target audiences and express a range of political orientations. While the political differences between the newspapers are often marked, our research did not reveal any strong distinctions among the titles in terms of how they reported the issue of 'violence' in relation to protests at Shannon airport. We do not consider, therefore, that much purpose would be served by rehearsing here the spectrum of political opinion that exists across the eleven publications.

The time frame captured the escalation of the Iraq crisis in autumn 2002, incorporating the first incidence of 'direct action' against a US military plane at Shannon; key events such as the declaration of 'mission accomplished' by President Bush were included by examining coverage through to May, though in truth the anti-war movement was little reported by that time. During the period covered by the research only one Irish newspaper, the Irish Times, was included in Lexis Nexis. As a result, it was not possible to analyse the reportage provided by the eleven titles using a digital search engine. The data was gathered and analysed instead by one researcher employed by the group for the period of a year who examined every single news page of every single newspaper selected. This painstaking work unearthed a total of 505 stories related, in part or in whole, to the anti-war movement and each of these was coded in two datasets.

The first dataset simply records the date of each article, the bylined reporter(s), the headline, the section and page it appeared on, its length in paragraphs and whether a picture appeared with it. Each article was also coded according to the story subject and the initiating source. This data underlines the importance of the articles studied: these stories that dealt in whole or part with the anti-war movement in Ireland averaged more than 10 paragraphs each; 44 of them appeared on front pages, 111 in the first three pages, 159 
in the first five pages, and 245 (nearly half the total) in the first seven pages of their papers. It is evident that not only the Iraq War itself but also the protest movement against it stood at or near the top of the news agenda throughout much of this period.

In the second dataset, information contained in the text of each article was recorded by the same member of the research team. Words and phrases in various thematic categories were noted as they appeared in the headline and the text of each article. (Note was also taken of whether the word or phrase was in a quotation or unattributed.) The current paper is based mainly, but not exclusively, upon studying the articles coded as containing 'implications of violence' in relation to the anti-war movement. As will become clear below, the diversity of journalists' approaches within this broad theme means that its appearance does not in itself give rise to conclusive data, but rather offers guidance to material that merits close examination by the research team. Such close reading indicates that not all stories coded as containing 'implications of violence' can be read as detrimental to the antiwar movement, nor even as evidence of the presence of a negative violence-based framing of protest.

Our database suggests a strong correlation, nonetheless, between 'implications of violence' and anti-war protests at Shannon. Apart from a string of Dublin demonstrations in March and April of 2003, the national press largely reserved 'violence' angles, of various kinds, for stories relating to activities at Shannon Airport, where the Irish army was deployed in February 2003 to provide security. At certain moments, the coverage was arguably more playful than critical: 'Peace groups still on warpath' (Evening Herald, 25 February 2003), for example, was broadly accurate in its characterisation of the divisions then becoming visible within the anti-war movement preceding the demonstrations at Shannon on 1 March. Such playfulness was an exception, however, as shown by the following chronological analysis of the development of coverage of Shannon, including coverage that did not feature violence references, over the course of the nine months of newspapers that we studied.

\section{'Not content to carry out a peaceful protest'}

In the autumn of 2002, when anti-war activity was still peripheral and smallscale, 'direct action' at Shannon attracted little opprobrium. When protester Eoin Dubsky was arrested at Shannon Airport on 4 September 2002 after daubing a US plane with anti-war graffiti, the press largely characterised the incident as a worrying security breach that might suggest Shannon's vulnerability to violent intruders, not as an act of violence in and of itself. There was one clear exception: on 5 September, the Irish Daily Star published an article whose headline called Dubsky's action an 'attack'. A 'senior garda [police] 
source' was quoted as saying, 'If peace activists can get in, I shudder to think who else can try.' The same quote was used in that day's Evening Herald, which positioned the story next to an unrelated article headed: 'Terror as man sneaked onto jet unnoticed'.

All the papers quoted Garda Inspector Tom Kennedy in court, citing an earlier encounter with the defendant: 'On that occasion he was very uncooperative and is not content to carry out a peaceful protest.' The policeman's implication that graffiti on an airplane constitutes non-peaceful protest attracted no comment and was not widely echoed in the coverage.

At this early stage, anonymous sources within the Garda (Ireland's national police force) reserved most of their wrath for the separate airport police, depicted as worryingly lax, rather than the protesters. (Tension between the Garda and airport police had been high for some years, since the latter saw their powers increased in the 1990s, and such hostile spinning is not unique to this story. See, for instance, The Irish Times [1999].) In the Evening Herald of 11 September 2002, a 9/11 anniversary article represents the crest of this brief wave of fearful stories. 'It's plane sailing for terrorists,' the headline reads, with the sub-headline continuing: 'Ireland could be an easy target if Shannon is anything to go by.' The story, based on anonymous sources, described variously as a 'garda' and a 'counter terrorism official' and possibly the same person, cites the force's 'fear and exasperation', mainly with airport police. The key passage read as follows:

\footnotetext{
"You tell me how in the hell on a night when there is an obvious US military presence at the airport and at such a sensitive time as this, that the perimeter can be so easily breached.

"And whatever about that. How could people stroll up to a military aircraft and let rip with spray cans? It beggars belief," a garda source said ... .

"Whether it's the case here or not, the fanatic sees only a symbol of the west, a symbol of capitalist and godless inequality. Project that logic on to any Irish asset of note," warned a senior Irish counter terrorism official.
}

This story's indirect linking of protest with violence was unusual for this early period in the study. Only 25 stories distributed across the full range of newspapers returned to the theme at all between the Dubsky incident in September 2002 and the hatchet attack on a US plane by campaigner Mary Kelly at the end of January 2003. (We discuss coverage of the latter incident in some detail below.) Only one of them featured on a front page, and only three more were placed on an inside right-hand page. The front-page exception was the Sunday Tribune's lead story of 12 January 2003, followed up inside the paper, headlined 'Shannon airport target for al Qaeda'. Other newspapers turned to the same specific theme in January as part of their coverage of the growing public knowledge and concern about the use of Shannon by US troops. A page-2 headline, 'Shannon is a top target for Osama', was the Irish 
Daily Star's contribution on 13 January, while 'The troops that make us a terror target', was the Irish Independent's page-3 version on 18 January.

While these stories do associate the situation at Shannon with the prospect of violence, perhaps contributing to tension around protest there, they do not directly tar the anti-war movement with that association. Indeed, the highlighting of a 'terrorist threat' to Shannon, coming from external Islamists not connected to Irish anti-war protest, could be said to serve the purposes of the anti-war movement: if Shannon were in fact a possible target, then perhaps US troops and equipment should not be facilitated there. There was, in this period up to late January 2003, no emphasis on violence or the prospect of violence among protesters in the national press.

Even when an emphasis on violence was potentially available it was adopted only rarely. The national press afforded little attention to the demonstration at Shannon on 12 October 2002, which saw 10 people arrested after more than 100 breached a perimeter fence at the airport. In the Sunday Independent of 13 October, for instance, it merited only a short 'news in brief' article on page 2, describing an 'unprecedented breach of security by anti-globalisation [sic] protesters'. The same day's Sunday Tribune had a largely sympathetic interview with Shannon anti-war 'planespotter' Tim Hourigan. The Monday morning reports of the breach by Pat Flynn in both the Irish Daily Star and Irish Examiner and by Gordon Deegan in the Irish Times were not prominent; and while Flynn's first paragraph noted that 'a peaceful anti-war protest turned ugly', both journalists quoted anti-war activists without comment or implied criticism. This October demonstration and its confrontation between police and protesters became a central theme of much local media coverage in Clare for months to come, evidence for ascribing 'violence' to protest (Browne, 2008, pp. 98-99); but it was rarely mentioned in national press.

\section{The information counterframe}

There was no coverage at all of the anti-war movement at Shannon in the national press in November 2002, then 15 articles in December and a marked increase to 59 articles between 1 January and 27 January. This coverage was overwhelmingly along lines that were sympathetic to the concerns of the Shannon protesters, and it quoted them extensively. In January especially, these stories were framed predominantly in terms of the information activists on the scene were providing about the scale of US troop activity at the airport, and of the debate they were raising about Irish neutrality in that context. Confusion on the part of the state, and the mainstream media, about what this meant demonstrated in an acute way what Dittmer and Parr (2011, p. 138) call the 'fundamentally insubstantial, discursive nature of sovereignty'. The government's main response was to suggest that nothing unusual was 
happening at the airport - a tactic that left the authorities highly vulnerable to new information, often coming from the anti-war camp. As one scholar of successful oppositional framing puts it: 'In these cases the news media can play a critical role by legitimating oppositional frames that increase the status, resources, and power of challengers' (Wolfsfeld (1997) quoted in Negrine \& Stanyer, 2007, p. 72).

The Shannon 'peace camp' (a literal encampment at the fringe of the airport) and 'peace house' (a nearby home that was a centre for plane-spotting of US aircraft), sites of protest that rarely hosted more than a few dozen people, saw their frame legitimated during this period across a wide range of newspaper titles. On 7 January, the Irish Independent ran a large photograph across the top of page 9, showing a photogenic Shannon protester holding a sign inviting passing motorists to 'beep for peace'. An accompanying story reported that a group of hillwalkers in Sligo, about 100 miles north of the airport, said they had seen US military planes flying in formation. Its opening phrase may be regarded as emblematic of this period: 'The Department of Foreign Affairs has been unable to explain ...'

On 9 January 2003, the Irish Independent, Irish Daily Star and Evening Herald all ran big stories about the US troop presence at Shannon, employing the same photo of a handsome young US soldier staring out an airport window. The shot was both poignant and, with its long-lens paparazzi-style flatness, suggestive of a secret that had slipped out. The following day, the Irish Independent ran a short piece by a political reporter headlined: 'Cowen urged to explain role of Shannon in US war move'. Once again, it seemed explanation from foreign minister Brian Cowen was in short supply. The following weekend, 11 and 12 January, saw the Irish Examiner, Sunday Tribune and Ireland on Sunday devote long, sympathetic articles to the Shannon anti-war campaigners, emphasizing the camp's female base and its survival in the face of cold weather. Ireland on Sunday on 12 January cited airport workers who provided 'evidence to refute the Government's assurances that the aircraft are unarmed troop carriers'. This question of whether soldiers passing through Shannon were armed, and if so whether they had permission to carry weapons in Ireland, was a focus of media attention for the following week.

On 13 January 2003, an Irish Independent headline, referring to Taoiseach Bertie Ahern, stated: 'Ahern denies Shannon role in build-up to war', though the quotes in the story were more equivocal than the headline suggested. 'I don't think it's correct,' he said, apparently in response to claims that the state was knowingly facilitating the movement of weapons through Shannon. The government appeared defensive. The front-page story in the Irish Examiner of 14 January 2003 quoted foreign minister Cowen to the effect that the soldiers' guns were not loaded, and therefore exempt from notification rules. 
The Shannon story was largely neglected in the most elite-oriented of Irish newspapers, the Irish Times, until 18 January when its human-interest features writer, Kathy Sheridan, authored an overwhelmingly positive story about the peace camp on the front of the paper's Weekend supplement. Protesters Caoimhe Butterly and Mary Kelly were praised for their previous, hazardous, Middle-East campaigning, and Kelly was paraphrased explaining why they had to camp at Shannon. 'The job, she [Kelly] says, is to monitor the aircraft and to bring this to public attention.' Later in the long piece there was a sympathetic account of the efforts of another campaigner, Tim Hourigan, to debate foreign minister Cowen on a TV current-affairs show, and readers were invited to conclude that the minister had evaded the debate because Hourigan would have overwhelmed him with information, based on his direct observations, about US military flights carrying troops and weapons. Both protesters, Kelly and Hourigan, were portrayed as purveyors of information that the government could not, or would not, offer, their role being to 'monitor' activities at Shannon - their role as 'protestors' seemed almost secondary.

A story in the following day's Sunday Tribune, by well-connected political journalist Stephen Collins, was effectively a strategic concession of defeat by the government on 'information':

THE Irish government has complained to the US authorities about the failure to provide full information about the number of flights going through Shannon airport carrying military personnel and weapons.

All charter flights carrying military personnel, which account for the vast bulk of the troop movements at Shannon, should be notified in advance to the Department of Transport, but this did not always happen.

In the past two weeks, there has been a big increase in the number of chartered civilian aircraft carrying US troops through Shannon. Most of the planes are carrying soldiers and their weapons to the Gulf.

There was concern in government that no notification or late notification had been provided in relation to some of the US flights, but sources say the problem has been rectified. (Sunday Tribune, 19 January 2003)

Analysis of subsequent coverage indicates that this prominent story, which presented the lack of official information about troop and weapons movement through Shannon as a bureaucratic misunderstanding that had now been 'rectified', marked the abrupt end of protesters' successful information counterframe. No longer would the anti-war movement earn sympathetic column inches for its 'revelations' about activities at Shannon: not a single story after 19 January takes up that theme. The government was no longer denying that things had changed there.

Did the government's admission, and thus closure of the 'revelations' route to press coverage, influence any subsequent tactical decisions by the anti-war movement, including the small but politically significant turn toward 'direct 
action' at the end of January? While the question cannot be fully addressed in the current research, which is based simply upon newspaper coverage, our own discussions with activists and the extant literature, such as Browne's (2008) account of that turn, suggest that any such direct causal link was unlikely. While in mid-January 2003 the political differences within the broad Irish anti-war movement (among pacifists, anarchists, Trotskyists and others) were latent rather than manifest, at least in public, the movement's intentions could not, then or later, be accurately described in unitary terms; the emergence of physical attacks on US aircraft at Shannon was a minor and contingent development, carried out by a small number of people with deep personal motivations and histories of radical protest. Moreover, as will become clear below, that development was unpopular with a wide swathe of anti-war spokespeople whose own tactical priority was in line with the international movement's plans to build the largest possible (strictly lawful) demonstration against the prospect of war, on 15 February - a priority that would earn them largely favourable press coverage.

\section{'Violence' returns}

Mary Kelly, a key figure of the information counterframe, re-emerged as a central player in the framing that soon followed, with considerable intensity, namely the association of violence with the anti-war movement. Her hatchet attack on a US Navy plane on the runway at Shannon on 29 January 2003, followed on 3 February by five Catholic Worker activists (the 'Pitstop Ploughshares') who did more damage to the same plane in its repair hangar, was a catalyst for a fundamental change in the dynamic of national press coverage of the Shannon anti-war movement and its relation to 'violence', even if the favourable treatment of the 15 February demonstrations in Dublin and around the world (see, e.g. Davies, 2012; Robinson et al., 2010) tended to obscure and delay that development.

The first press story of Kelly's arrest, on the front page of the Evening Herald on 29 January 2003, recycled several paragraphs from a largely negative profile that had appeared some days earlier in its sister publication, the Sunday Independent. 'Mary Kelly has been described as a globetrotting professional protester,' the un-bylined Herald story states, without noting that this description originated with the Sunday Independent. The story's third paragraph quotes an unnamed 'investigating officer': 'From what we can make out it was a frenzied attack.' (This suggestion of atavistic anger is unique in coverage of anti-war 'violence' in this study.) This story, like one on 30 January in the Irish Daily Star, used the word 'Mum' in its headline to refer to Kelly, as if to contrast the ostensibly peaceful, nurturing qualities of motherhood with Kelly's hatchet-wielding exploits. The fact that Kelly was both 'mum' and 'nurse' (the latter profession was mentioned too) made her 
doubly vulnerable to such irony. No coverage of Kelly in this period acknowledged in any way that she had previously been employed by journalists as an admirable source.

The Sunday Independent of 2 February 2003 ran what might be called its own second 'hatchet job' about Kelly on the front-page. A story headlined 'Shannon hatchet activist is feted by republican diehards' began:

"PEACE ACTIVIST" [note inverted commas] Mary Kelly, arrested after a hatchet attack on a United States Navy transport plane in Shannon which caused $€ 500,000$-worth of damage, has been honoured in New York by supporters of the dissident Republican Sinn Féin (RSF) group, which has links to the Continuity IRA. (Sunday Independent, 2 February 2003)

The story was based on the fact that Kelly had been due to be guest of honour at an Irish-American gathering. The story offers no evidence of Kelly offering support to paramilitary violence. Indeed, as a story in the same day's Ireland on Sunday made clear, Kelly had much closer ties to a different military organisation: Ireland's legitimate and official army - both her father and brother were officers in the Irish Defence Forces. The Ireland on Sunday article, given a full page inside the tabloid, led with the alleged anger of a family 'steeped in military tradition' being 'dragged into such an incident'. It continued: 'Friends and family are mystified as to how she transformed from an ambitious nurse with bright prospects into a hippie peace campaigner who believed in free love and had four children by four different men' (Ireland on Sunday, 2 February 2003). However, once it had attempted to titillate readers with this colourful biographical detail, the story highlighted favourable comments about Kelly and her political commitments from friends and associates. Ireland on Sunday quoted then Green Party leader Trevor Sargent's unstinting encomium to Kelly: 'Mary has really taken to heart "think globally act locally". When she sees an injustice she tries to do something about it .... She is widely respected as a person of commitment' (Ireland on Sunday, 2 February 2003).

Early in the morning on the day after that story appeared, the Pitstop Ploughshares took their own similar but larger action at Shannon, doing further damage to the same US Navy plane, breaking into a hangar, hitting the aircraft with a pick-axe and smaller hammers. They also built a shrine to the Iraqi victims of bombing and sanctions outside the hangar and daubed slogans including 'Pitstop of Death'. They were eventually arrested without resistance. These five activists, including an Australian, an American and a Scot, did not benefit from the local familiarity that had tempered coverage of Kelly. When Ireland on Sunday turned to them and their action, the article (9 February 2003) was headlined 'blood sacrifice' and 'runway voodoo'; the fullpage story, despite five days for research between the arrest and the deadline, included only one quote from anyone who knew any of the defendants, a Holy Ghost priest speaking about Irish-born seminarian Damien Moran. 
Compounding this ignorance in tilting coverage against them was the fact that theirs was the second attack, embarrassing to gardaí and politicians who had said no repetition of the Kelly incident was possible. Some people in the anti-war movement who had been supportive or silent about Kelly expressed opposition to this second Shannon attack. Some were under the mistaken impression, based on misleading Garda information, that the Catholic Worker group had 'overpowered' a policeman - an allegation that didn't last long enough to feature significantly in print-media coverage of the event, but was prominent for several hours in broadcast coverage (Browne, 2008, pp. 77-78).

As with Mary Kelly, because of the early-morning timing of their arrest the first national-press reporting of the Pitstop Ploughshares incident came in the Evening Herald. The newspaper deployed the word 'Catholics' much as it had done 'Mum' for Kelly, with a massive front-page headline: 'The "Catholics" [note again the inverted commas] who invaded Shannon', with the subheading 'Second highly embarrassing security breach' (Evening Herald, 3 February 2003). The article's emphasis on the government's embarrassment and its headline use of the verb 'invade' - the noun 'raid' then occurs in the third paragraph of the article - suggests an upgrading of the press's linguistic arsenal in relation to anti-war activities.

After this second 'invasion', the Irish government and the anti-war movement were now, it seemed from the press coverage, preparing for their own battle in Shannon. The tone was set in an angry broadcast interview with the Taoiseach (Prime Minister), Bertie Ahern, reported in the Irish Times on 4 February and in other newspapers. He said: 'Maybe we were a bit over-tolerant of peaceful protesters, when they are not peaceful protesters, carrying hammers, lump hammers and pick-axe handles.' The Irish Independent (4 February 2003) headlined on its front page an Army-Garda 'security ring' at the airport; the same day's Irish Examiner lead story called it a 'ring of steel'. The Irish Times led with the more restrained 'Cabinet set to approve use of Army to guard US planes', while its story on the top of page 3 described the immediate deployment of armed Garda detectives. The impression in this report of a war scene, or at least a Cold War scene, is unmistakable: 'The detectives, armed with Uzi machine guns, were patrolling in icy conditions the immediate vicinity of the old SRS hangar where a US navy cargo aircraft was attacked early yesterday' (Irish Times, 4 February 2003). 'Stop, or risk being shot' was the Irish Daily Star's headline response to the same events (4 February 2003). Green Party leader Trevor Sargent was quoted in the Evening Herald (4 February 2003) as stating carefully, 'I oppose any law breaking or damage to property which constitutes law breaking,' but that he couldn't state whether these actions constituted law-breaking. In light of the eventual acquittal of the Pitstop Ploughshares in 2006, and the later quashing of Mary Kelly's conviction, he was prescient: Sargent 
had visited Kelly in jail and knew of the likely, and ultimately successful, legal defence to the charges of criminal damage faced by all the defendants. He was attacked by the Government chief whip for expressing this view (Irish Examiner, 5 February 2003). Virtually no one else was as careful as Sargent: even the Irish Times was rash enough to call the accused 'lawbreakers' (editorial, 4 February 2003, not included in our database, which looked only at news coverage).

There was a discernible shift at this time in terms of who was reporting Shannon-related stories. A news location that had previously been covered by a mix of regional, political and general-interest reporters was now more often in the hands of crime and 'security' specialists - those Uzis in icy conditions, for example, were observed by Irish Times crime correspondent Conor Lally. In this context, it is no surprise that the subsequent coverage tends to depict the forces of the State seeking to maintain law and order as opposed to the earlier depiction, in which the voices of government had been either silent or confused in the face of protesters' information about US troop movements.

While some media caution soon re-established itself in relation to the charged defendants in the Shannon direct-actions - typically, due to sub judice restrictions, Irish 'crime' stories disappear between the charging and the trying of accused people - the new atmosphere was sufficient to cause the Shannon peace camp to disband, amid stories of emotional divisions about 'direct action'. However, perhaps due to that caution, Kelly and the Pitstop Ploughshares were rarely directly described with the word 'violent': the implication tended to arise by contrast with 'peaceful protest', a phrase generally employed as though it were the opposite of their actions. A story in the Irish Examiner, headlined 'Alliance criticises protesters', began:

\footnotetext{
Children who planned to attend next week's Dublin protest against the war in Iraq have been told they cannot travel because of the actions taken by some protestors [sic] at Shannon.

Brendan Butler of the NGO Peace Alliance, revealing his group's opposition to the targeting of United States-chartered aircraft [sic, the plane in question was part of the Navy's own fleet] said it was the wrong strategy as it would alienate some who would otherwise support the anti-war camp....

"We have always called for peaceful protest and we are not involved in direct action," Mr Butler said. (Irish Examiner, 5 February 2003)
}

The marginalisation of Kelly and the Pitstop Ploughshares that runs through the media coverage of 4 to 6 February, in particular, was based in part upon statements from other elements of the anti-war movement, such as Butler above. This was arguably a case of a protest movement following the pattern posited by Gitlin $(1980$, p. 3 ) and submitting itself to the logic of the media, with its policing of the boundaries of legitimacy. The dynamic created by the direct-action focus on Shannon Airport and the resulting 
divisions in Irish anti-war activity are peculiar perhaps to the Irish movement and media; our research suggests that they led to some media delegitimising of protest at a time when elsewhere in Europe (Dimitrova \& Strömbäck, 2008; Robinson et al., 2010), anti-war protests garnered sympathetic coverage. In contrast to what prevailed in other countries, Irish media coverage of the anti-war movement had a decidedly negative cast some weeks before the war began on 19 March.

\section{After the 15 February demonstrations}

In the days between 23 February and 3 March 2003, there were 40 separate press stories coded in our study as including 'implications of violence' about the anti-war movement. This rash of such coverage is particularly striking, because there were no stories at all in any national newspaper coded in our research for containing any 'implications of violence' on any date from 18 to 22 February - a five-day gap that is the longest that occurs between late January and the end of March; this finding indicates, perhaps, the benign effect of the global 15 February demonstrations. Davies (2012) and Robinson et al. (2010) discuss the phenomenon of the media bowing to the perceived 'ordinariness' of that day's demonstrations in a non-Irish context. However, in that gap, as is documented in other strands of our research, the Irish political establishment began to take a more aggressive political and economic stand against the anti-war movement (Coulter et al., 2016). That fact, and tactical differences within the movement, conspired to produce nine challenging publication days from Sunday, 23 February to Monday, 3 March.

Every story relating 'violence' to the anti-war movement in this nine-day period related in some way to the protests planned and executed at Shannon on Saturday, 1 March. Crucial to understanding this focus, and the 'violence' construction, is the knowledge that two separate demonstrations were scheduled at Shannon on that date, one called by the Grassroots Network Against War (GNAW), sympathetic to direct action and calling for a 'mass trespass' at the airport, and another by the Irish Anti-War Movement (IAWM), assumed to be a 'normal' political march and rally. A further complication was that some groups affiliated to the IAWM disassociated themselves from its protest because of fear that it would be associated with the GNAW action. (See Gillan et al. (2008), Seppälä (2012) and Sinclair (2013) on similar dynamics within the British anti-war movement.) The distinction between two protests was lost on reporters and headline writers, who couldn't squeeze this literal plurality into their stories. Some headlines illustrate the point:

Alert over huge Shannon protest (Irish Independent, 26 February 2003)

Shannon protest plan criticised (Irish Times, 27 February 2003)

Shannon march plan 'concern' (Irish Daily Star, 28 February 2003) 
US war protest loses support (Irish Daily Star, 1 March 2003)

Soldiers put up razor wire to block Shannon anti-war protest (Irish Examiner, 1 March 2003)

Shannon protest hit by more defections (Irish Independent, 1 March 2003)

The singularity, common to all the dailies, continued after the demonstration, for example 'Shannon protest passes peacefully' (Irish Daily Star, 3 March 2003) and ' $1 \mathrm{~m}$ euro bill to police war Shannon demo' (Ireland on Sunday, 2 March 2003). Headlines reflecting the reality of multiple demonstrations organised by separate groups were rare, and included a presumably tongue-in-cheek one in the Irish Times on the day of the protest: 'Irish peace movements deny split' (1 March 2003).

Both the confusion about the number of demonstrations and the excitement about security arrangements are typified by a story in the Irish Examiner:

SOLDIERS added razor wire to Shannon Airport's perimeter fences last night as the army and gardaí braced for trouble at today's anti-war protest.

In the last couple of weeks the army has been training troops in additional riot tactics for today's rally, a source confirmed yesterday.

Spokesman Kieran McDaid said extra troops and equipment would be dispatched for today's march.

A group calling itself the Grassroots Network Against War last night said it would breach the perimeter fence at today's demonstration.

"We will not attempt to occupy the runway or to reach any planes. The purpose of this action is to demonstrate that the State cannot secure the 'warport' against the anger of the people," said a spokesperson.

The original organisers of the march, The Irish Anti War Movement (IAWM), denied any connection with the Grassroots Network.

The group said it expected several thousand people to protest peacefully. IAWM spokesman, Richard Boyd Barrett, said the proposed breach of security would detract from the real issues of the protest.

The prospect of violence at Shannon has split the anti-war movement, deterring others from attending the protest .... (Irish Examiner, 1 March 2003)

The incorrect and widely repeated assertion that the IAWM was 'the original organisers of the march' and the necessity that it 'denied any connection' with a rival group and action was accompanied by the spectacle of succeeding groups characterising their own demonstrations as 'peaceful' as a means of contrasting them with others - and on this point journalists cannot be blamed.

The avowedly symbolic action proposed by GNAW, to get to the perimeter fence and by tearing it down to demonstrate the insecurity of the airport, was almost inevitably turned by both the press and rival campaigners into 'the prospect of violence', but without any analysis of how that violence was most likely to come about, i.e. through the 'riot tactics' of the police who were 'braced for trouble'. The unlikelihood of the protesters reaching and breaching the fence, given the pre-publicity and police presence, was never 
mentioned. The riot squad was an object of journalistic interest, featuring in near-identical Irish Daily Star headlines on 26 February ('Riot cops at Shannon') and 27 February ('Riot cops to head for Shannon'), and the more excitable Irish Independent, 'Riot squad to lead charge on airport protesters' (28 February 2003). The 'threat of violence' was understood to come from certain protesters, as in the headline 'Anti-war movement split over threat of violence at Shannon' (Irish Independent, 27 February 2003).

Reports after the fact were of necessity rather anti-climactic. 'Gardai hold off rampage at Shannon' was the dramatic headline in the Sunday Independent (2 March 2003) over a report that called the event 'good natured'. In a colourful report in the news pages of the Evening Herald, Richard Delevan mocked the GNAW demonstration, employing the range of stereotypes of young incoherent middle-class protesters identified by Adler and Mittelman (2004) in their study of coverage of the anti-globalisation movement:

\footnotetext{
Resistance, as it turned out, was futile.... .

On the one side, some 300 protesters who looked just as if they'd mistakenly walked off the set of an Avril Lavigne video (ask your kids) and dazedly stumbled into the real world ....

On the other, a virtual Maginot Line of gardaí ....

Both groups seemed to be milling around. Riot cops leaning on plastic shields, looking bored. Equally bored protesters from the rival anti-war march walking back to the terminal with their kids.

Even before it had really begun, the protest hadn't gone to plan. Spooked by the possibility of violence, many of the anti-war groups (there are a lot of them) called on their supporters to stay away. (Evening Herald, 3 March 2003)
}

With help from press that had hyped a 'prospect of violence', the anti-war movement had been made to look divided and ridiculous.

After the spate of stories anticipating and covering these demonstrations, Shannon had a far lower profile in press coverage of the anti-war movement from early March onward, becoming something of an abstraction in discussions of the war and its political implications in Ireland. Much of the antiwar activity reported during March 2003 took place in Dublin. In the Irish Times of 6 March 2003, the Tánaiste (deputy Prime Minister) Mary Harney said, according to the reporter who paraphrased her, that 'some people appeared to be determined to close down Shannon Airport'. In this case, however, the hyperbole about the intentions of anti-war activists did not attract prominent placement or reaction. As elsewhere (see, for instance, Goddard, Robinson, and Parry (2008) on British discourse in this period), the politics of anti-war arguments faded completely once the bombing began.

The rest of the period studied for this research, up until the end of May 2003, saw press interest in the anti-war movement continue to fall, and likewise coverage of Shannon. The airport as an actual location, rather than as a name thrown into debate about foreign policy and its economic 
consequences, scarcely featured at all in news coverage. One exception was the arrest on Good Friday, 18 April, of two further self-described 'Catholic Worker' activists (unrelated to the February group) who breached the airport's perimeter fence and built a shrine near a runway - a story that got no page- 1 coverage on the first day and no coverage at all in the six remaining weeks of our study period.

\section{Conclusion}

While violence framing did come to dominate press coverage of anti-war activities at Shannon, we find this only occurred after late January 2003. In fact, we note a number of events prior to that date that might have, but did not, give rise to much coverage with a focus on 'violence'. The attachment of an implication of violence to aspects of anti-war activity, though rarely entirely absent, was prevalent in the print media for about five weeks, from the time of campaigner Mary Kelly's 'disarmament' with a small axe of a US Navy aircraft at the airport on January 29 through to the coverage of protest events on 1 March, when competing factions of the anti-war movement converged on the airport. This recognition of its temporal limitations is not, however, to minimise the importance of the framing: the month-long period of violence framing coincided with the height of the anti-war movement's popularity and visibility, and inter-factional arguments about direct action and 'violence', including over the making of denunciatory press statements that associated the one with the other, featured prominently in activists' accounts of why Irish anti-war activity waned from March onward (see Browne, 2008).

The account and analysis above are suggestive not merely about the vicissitudes of press coverage of anti-war activities at Shannon Airport, but also about the circumstances under which oppositional narratives and arguments can thrive in a contentious, and often hostile, media environment. There was, at the turn of 2002-03, a brief period of frequent and positive coverage of the anti-war movement at Shannon, peaking in mid-January 2003; the research suggests this was not simply a phase in a cycle, but that the movement's successful dissemination in the press of a counterframe was contingent on poor information from official sources, and the capacity of protesters present at and near the airport to provide data of their own. It became clear, given the availability of visual evidence largely supplied by activists, that the Irish government could not sustain assertions that there was nothing new or different about US military use of Shannon in this period. Once Irish officials admitted that Shannon was involved in transporting large numbers of troops and munitions, claiming they had been kept in the dark themselves by their US counterparts, sympathetic exposure of the movement's information counterframe vanished completely. The word 'completely' is not, here, a sweeping generalisation but rather an empirical description. We would not seek to 
deny the existence of plurality in Irish newspaper coverage of the anti-war movement - Irish newspapers differ, and those differences may be visible in the opinion articles in these titles during this period. However, in news coverage relating to Shannon, the only divergence from the strict periodisation of consensual norms that emerges from our study is the Sunday Independent's negative article about Mary Kelly on 26 January 2003, a few days before she inflicted damage on a US Navy aircraft - a divergence that is of some interest, perhaps, but hardly the basis for any further exploration of plurality.

That article was, in any case, less an outlier than a harbinger. From 29 January into March, the coverage of anti-war activity at Shannon across all newspaper titles was dominated by the implication of violence, a more familiar framing for protest. Once the press settled into using the violence framing, the continuing diffusion of a successful counter-narrative about Shannon became increasingly unlikely; divisions within the movement about Shannon tactics arguably damaged any prospect of restoring any counterframe - about, say, the 'should' of US troops at Shannon rather than the 'whether' - even while the broader anti-war movement outside Shannon got additional weeks of relatively sympathetic coverage. The month of March saw Shannon cease to feature in any significant way in press coverage. Although Ireland was now effectively a member of the 'Coalition of the Willing', the principal site of that membership hardly merited mention. When the incomparable capacity of US military violence was finally unleashed on Iraq, the news pages of Irish newspapers failed to acknowledge the irony that they had devoted weeks of high-octane coverage to 'violence' that took the form of a cut in a fence or a hole punched in an aircraft engine.

Our observations, grounded as they are in the contingencies of the Irish debate, nonetheless provide further evidence as to the well-established relevance of violence framing of protest movements; but they also tend to support the conclusion of Boyle et al. (2012) that negative framing is most likely to arise when media are able to focus on protest tactics rather than protest goals, and also offer some evidence for the existence of Gottlieb's (2015) 'protest news framing cycle'; finally, our study suggests that a protest campaign's focus on providing information, especially in circumstances where official information sources are poor or ambiguous, offers the potential for successfully fostering a mediated counterframe.

\section{Disclosure statement}

No potential conflict of interest was reported by the authors.

\section{Funding}

This work was supported by Joseph Rowntree Charitable Trust. 


\section{References}

Adler, G., \& Mittelman, J. H. (2004). Reconstituting 'common-sense' knowledge: Representations of globalization protest. International Relations, 18(2), 189-211.

Allen, K., \& Coulter, C. (2003). The Irish Republic, the United States and the Iraq War: A critical appraisal. Dublin: Irish Anti-War Movement.

Baden, C., \& Tenenboim-Weinblatt, K. (2018). Viewpoint, testimony, action. Journalism Studies, 19(1), 143-161.

Barbrook, R. (2007). Imaginary futures: From thinking machines to the global village. London: Pluto.

Boyle, M. P., McLeod, D. M., \& Armstrong, C. L. (2012). Adherence to the protest paradigm: The influence of protest goals and tactics on news coverage in U.S. and International Newspapers. International Journal of Press/Politics, 17(2), 127-144.

Browne, H. (2008). Hammered by the Irish: How the Pitstop Ploughshares disabled a U.S. war-plane - with Ireland's blessing. Oakland: Counterpunch/AK Press.

Browne, H. (2011, June 3-5). Dublin Wikileaks cables reveal Irish Govt. Groveling to the US. Counterpunch. Retrieved from http://www.counterpunch.org/2011/06/03/ dublin-wikileaks-cables-reveal-irish-govt-groveling-to-the-us/

Cammaerts, B. (2012). Protest logics and the mediation opportunity structure. European Journal of Communication, 27(2), 117-134.

Carruthers, S. L. (2011). The media at war (2nd ed.). Houndmills: Palgrave.

Cottle, S. (2008). Reporting demonstrations: The changing media politics of dissent. Media, Culture \& Society, 30(6), 853-872.

Coulter, C., Browne, H., Flynn, R., Hetherington, V., \& Titley, G. (2016). 'These people protesting might not be so strident if their own jobs were on the line': Representations of the 'economic consequences' of opposition to the Iraq war in the Irish national press. Media, War \& Conflict, 9(2), 113-136.

Davies, M. (2012). Oppositions and ideology in news discourse. London: Bloomsbury.

Dimitrova, D. V., \& Strömbäck, J. (2008). Foreign policy and the framing of the 2003 Iraq War in Elite Swedish and US Newspapers. Media, War and Conflict, 1(2), 203-220.

Dittmer, J., \& Parr, D. A. (2011). Mediating sovereignty: A comparative latent semantic analysis of US newspapers and conflicts in Kosovo and South Ossetia. Media, War and Conflict, 4(2), 124-141.

Doris, M. (2007). The militarisation of Ireland's foreign and defence policy: A decade of betrayal, and the challenge of renewal. Dublin: Afri.

Entman, R. M. (2004). Projections of power: Framing news, public opinion, and U.S. foreign policy. Chicago: University of Chicago Press.

Gillan, K., Pickerill, J., \& Webster, F. (2008). Anti-war activism: New media and protest in the information age. Houndmills: Palgrave.

Gitlin, T. (1980). The whole world is watching: Mass media in the making and unmaking of the new left. Berkeley: University of California Press.

Goddard, P., Robinson, P., \& Parry, K. (2008). Patriotism meets plurality: Reporting the 2003 Iraq War in the British Press. Media, War and Conflict, 1(1), 9-30.

Gottlieb, J. (2015). Protest news framing cycle: How The New York Times covered occupy wall street. International Journal of Communication, 9, 231-253.

Hallin, D. (1986). The uncensored war: The media and Vietnam. Oxford: Oxford University Press.

Halloran, J., Elliott, P., \& Murdock, G. (1970). Demonstration and communication: A case study. Harmondsworth: Penguin. 
Hayes, D., \& Guardino, M. (2010). Whose views made the news? Media coverage and the March to War in Iraq. Political Communication, 27(1), 59-87.

Lee, F. L. F. (2014). Triggering the protest paradigm: Examining factors affecting news coverage of protests. International Journal of Communication, 8, 2725-2746.

Maeseele, P., Raeijmaekers, D., Van der Steen, L., Reul, R., \& Paulussen, S. (2017). In Flanders fields: De/politicization and democratic debate on a GM potato field trial controversy in news media. Environmental Communication, 11(2), 166-183.

McLeod, D. M., \& Detenber, B. H. (1999). Framing effects of television news coverage of social protest. Journal of Communication, 49(3), 3-23.

Miller, D. (Ed.). (2004). Tell me lies: Propaganda and media distortion in the attack on Iraq. London: Pluto.

Miller, R. (2005). From 11 September 2001 to the War in Iraq: Irish responses to the global 'war on terrorism'. Irish Studies in International Affairs, 16, 155-174.

Mirzoeff, N. (2005). Watching Babylon: The War in Iraq and global visual culture. London: Routledge.

Negrine, R., \& Stanyer, J. (2007). The political communication reader. London: Routledge.

Nineham, C. (2013). The people V. Tony Blair: Politics, the media and the anti-war movement. Winchester: Zero Books.

O'Regan, M. (2010). Political language as a flexible friend: Irish parliamentary debate on the Iraq War. Irish Political Studies, 25(1), 1-21.

Power, M. J., Haynes, A., \& Devereux, E. (2016). Reasonable people vs. The Sinister Fringe: Interrogating the framing of Ireland's water charge protestors through the media politics of dissent. Critical Discourse Studies, 13(3), 261-277.

Raid Shows Need for Co-ordination of Airport Security. (1999, November 1). The Irish Times.

Robinson, P., Goddard, P., Parry, K., Murray, C., \& Taylor, P. (2010). Pockets of resistance: British News media, war and theory in the 2003 invasion of Iraq. Manchester: Manchester University Press.

Seppälä, T. (2012). Globalizing resistance: Theories of resistance and the new anti-war movement. Abingdon: Routledge.

Shahin, S., Zheng, P., Sturm, H. A., \& Fadnis, D. (2016). Protesting the paradigm: A comparative study of news coverage of protests in Brazil, China, and India. International Journal of Press/Politics, 21(2), 143-164.

Sinclair, I. (2013, April 4). The stop the war coalition, the socialist workers party and Iraq. New Left Project.

Taylor, I. (2015). Towards a better understanding of how radical non-official sources approach media relations: The case of the British anti-war movement. Journalism: Theory, Practice \& Criticism, 16(2), 181-197.

Taylor, I. (2017). Media relations of the anti-war movement. New York: Routledge.

Tonra, B. (2006). Global citizen and European Republic: Irish Foreign policy in transition. Manchester: Manchester University Press.

Tumber, H., \& Palmer, J. (2004). Media at war: The Iraq crisis. London: Sage.

Wolfsfeld, G. (1997). Media and political conflict: News from the Middle East. Cambridge: Cambridge University Press. 